\title{
DAMPAK IMBALAN KERJA DAN HARGA POKOK PRODUKSI TERHADAP LABA BRUTO PT. UNILEVER INDONESIA, TBK.
}

\author{
Francisca Sestri Goestjahjanti \\ STIE Insan Pembangunan
}

Diterima 6-8-2020 / Disetujui 15-9-2020

\begin{abstract}
The growth of large-scale and medium-scale manufacturing industries in Indonesia today is not yet encouraging and tends to slow down year on year in the first quarter of 2019 and in the 2018 quarter, become down 0.80 percent, due to political temperatures heating up ahead of the presidential election. The rejection of the Omnibus Law made the Company to recalculate the determination of employee benefits which would affect company profits. This study aims to analyze the magnitude of the impact between employee benefits and the cost of good manufacture to the gross profit of PT. Unilever Indonesia, Tbk. Hypothesis test of this study becomes a reference in establishing the research method. By measuring the dependency between the influencing variables on the affected variable described the mind frame of the model. The analysis technique uses linear regression with the SPSS statistical program. The results of the study are: There is a significant impact between employee benefits on gross profit of 84.90 percent. There is a significant impact between cost of good manufacture on gross profit of 98.70 percent. And simultaneously there is a very significant impact of 99.10 percent between employee benefits and the cost of good manufacture to the gross profit of PT. Unilever Indonesia, Tbk.
\end{abstract}

Keywords: Employee Benefits, Cost of Good Manufacture, and Gross Profit

\begin{abstract}
ABSTRAK
Pertumbuhan industri manufaktur skala besar dan sedang di Indonesia dewasa ini belum menggembirakan dan cenderung mengalami perlambatan year on year kuartal I 2019 dan kuart1I 2018 menurun 0,80 persen, karena suhu politik memanas menjelang Pilpres. Penolakan UU Omnibus Law membuat Perseroan berkalkulasi ulang untuk penetapan imbalan kerja karyawan yang akan berpengaruh pada laba perusahaan. Penelitian ini bertujuan untuk menganilisis besarnya dampak antara imbalan kerja dan Harga Pokok Produksi terhadap laba bruto PT. Unilever Indonesia, Tbk. Uji hipotesis pada penelitian ini menjadi acuan dalam menetapkan metode penelitannya. Dengan mengukur keterhungan antara variabel memengaruhi terhadap variabel yang dipengaruhi digambarkan dalam model kerangka pemikiran. Teknik analisis menggunakan regresi linier dengan program statistik SPSS. Hasil penelitian adalah: Terdapat dampak signifikan antara imbalan kerja terhadap laba bruto sebesar 84,90 persen. Terdapat dampak signifikan antara Harga Pokok Produksi terhadap laba bruto sebesar 98,70 persen. Dan secara simultan ada dampak signifikan sangat besar yaitu 99,10 persen, antara imbalan kerja dan Harga pokok produksi terhadap laba bruto PT. Unilever Indonesia, Tbk.
\end{abstract}

Kata Kunci: Imbalan Kerja, Harga Pokok Produksi, dan Laba Bruto.

Korespondensi Penulis: sestri@ipem.ac.id, sestri.rahardjo@gmail.com 


\section{PENDAHULUAN}

Industri manufaktur besar dan menengah pada tahun 2019 di Indonesia sedang mengalami sedikit perlambatan, dibandingkan pada periode sama di kuartal satu year on year (yoy) mengalami penurunan yaitu dari 5,35 persen menjadi 4,55 persen, turun sebesar $0,80 \quad$ persen (Republika.co.id.ekonomi : 2019).

Hal ini terjadi karena investasi yang masih termangu, menyikapi suhu politik yang masih memanas menjelang Pilpres saat itu diselenggarakan bulan April 2019. Dengan demikian para investor menahan dan tetap wait and see akan seperti apa situasi kondisi perekonomian di Indonesia.

Awal tahun 2020 adalah babak baru datangnya musibah tragis yang tidak terduga sebelumnya oleh siapapun baik industri besar maupun tingkat Usaha Mikro Kecil dan Menengah (UMKM). Sektor ini terdampak oleh mewabahnya pandemik Covid-19 yang hingga diturunkannya tulisan ini pemerintah dan badan terkait masih melakukan penanganan-penanganan pencegahan baik bidang kesehatan, sosial dan ekonomi yang terus merosot pertumbuhannya.

Menurut BPS / Badan Pusat Statistik (2020 : 8 ) perubahan pendapatan menurut skala usaha di Indonesia yaitu menurun 82,85 persen, meningkat 2,55 persen dan relatif tetap sebesar 14,60 persen.

Sedangkan menurut klasifikasi ukurannya, jumlah Usaha Menengah dan Besar (UMB) mengalami penurunan pendapatan 82, 29 persen dan jumlah Usaha Menengah Kecil (UMK) yang mengalami penurunan pendapatannya 84,20 persen.

Keadaan demikian mendorong pertumbuhan ekonomi Indonesia minus di kuartal dua.

Pada posisi ekonomi slow down tersebut, maka perusahaan-perusahaan akan melakukan produksi selektif dan Harga Pokok Produksi akan di termaintance dengan baik sehingga laba perusahaan tidak tergerus oleh target-target operasional yang tidak relevan.

Pandemi Covid-19 yang masih belum ditemukan vaksinnya menjadi momok bagi dunia usaha, sehingga diera industry 4.0 caracara baru berbasis digital akan merubah mereka dalam menyikapi kenyataan dengan gaya bisnis yang berbeda, kreatif dan inovatif sebab pasar juga berubah terutama sejak diberlakukan PSBB maka perusahaanperusahaan banyak melakukan WFH (work from home).

Cara baru tersebut harus disikapi dengan berselancar dan melakukan shifting secara bertahap dari kompetisi berbasis produk (product base) beralih ke kompetisi platform base (Renald Kasali, 2018 : Iiii).

Disisi lain isu yang sedang mencuat dimasyarakat adalah penolakan Rencana Undang-undang Omnibus Law Cipta Kerja, menurut Konfederasi Serikat Pekerja Indonesia (KSPI) akan merugikan mereka dengan penghilangan sebagian hak-haknya yang masuk pada beban imbalan kerja dan menjadi tujuan para pegawai saat mereka sudah tidak bekerja lagi. Mahasiswa dan para buruh turun kejalan, menganulir bahwa UU Cipta Kerja hanya akan menguntungkan para pengusaha. (Tempo.co.bisnis:2019). Oleh karenanya apabila tuntutan KSPI dikabulkan, maka imbalan kerja menjadi bahan pertimbangan bagi pengusaha, mengingat besarannya cukup signifikan.

Tantangan dan hambatan bagi para manajer dalam perusahaan jauh lebih sulit apabila dihadapkan pada perbedaan religius, tardisi, budaya yang sudah mengakar dalam suatu lingkungan masyarakat majemuk (Stephen P. Robbins \& Mery Coulter, 2010: 115)

PT. Unilever Indonesia, Tbk. berstatus PMA, berdiri pada tahun 1933 dengan Akta Pendirian No 23 Tanggal 5 Desember 1933 dihadapan Notaris Andrian HendrikVan Ophuijsen. Perseroan sudah beroperasi di Indonesia sudah lebih dari 86 , dan berasal dari Belanda. Maka sudah barang tentu 
Unilever memiliki ikatan kuat dengan Indonesia.

Perusahaan Multi Nasinoanl kelas global ini berkantor Pusat di Bumi Serpong Damai (BSD) daerah Tangerang. Initial Public Offering (IPO) pada 11 Januari 1982, dengan mencatatkan saham perdana di Bursa Efek Indonesia yang terdiri Bursa Efek Jakarta (Jakarta Stock Exchange) dan Bursa Efek Surabaya (Surabaya Stock Exchange).

Perseroan yang bergerak dibidang industri manufatur produk kebutuhan rumah tangga dan kosmetik personal care ini terus maju dan berkembang. Dalam public expose diketahui bahwa awal tahun 2019, kapitalisasi pasar saham Unilever ada diperingkat ke lima terbesar skala nasional. (Laporan Tahunan,2018).

Pabrik Kosmetik Perawatan kulit (Skin care ) dengan berbagai merek terkenal diantaranya: Dove, Rumah Citra, Sunsilk, Pond's. Pabrik dibangun di Kabupaten Bekasi diatastanah seluas 10 ha, denganluas bangunan $22.500 \mathrm{~m}^{2}$,pada tahun 2008. Saat itu pabrik perseroan adalah terbesar di Asia. Desain dengan konsep ini merupakan bentuk komitmen investor asing yang sudah terbuka (go public) dalam memajukan industri kosmetik dan kebutuhan rumah tangga di Negara Indonesia.

Maurits Lalisang Direktur Utama pada saat itu, mengatakan investasi yang dikeluarkan sebesar 0,5 triliun dengan kapasitas 53.00 ton/tahun karena dari bisnis bidang kosmetik (skincare) yang berkembang pesat, tidak terlepas berkat sumbangan, kontribusi dan peran serta kaum perempuan Indonesia (Okezon:2008).

Industri besar dan sedang sekarang masuk pada situasi kesulitan serius, karena merebaknya pandemi virus covid-19 yang telah diuraikan sebelumnya, disinyalir akan memengaruhi kenaikan Harga Pokok Produksi kedepan. Hal mana sangat terkait sulitnya pengadaan bahan mentah dari luar negeri karena masih dalam tahap menuju new normal dan menjadi mahal karena langka, sangat dimengerti karena 70 persen lebih bahan baku, alat-alat produksi masih diimpor dari negara lain (Adhi Lukman GAPMMI, April 2020).

Bagi perusahaan yang sudah IPO yaitu telah mencatatkan sahamnya di Bursa Efek Indonesia (BEI) atau terbuka, tidak serta merta langsung naik terus profitnya namun harus memacu direksi mewujudkan kerja solid berintegritas agar tercipta "The winning team" disaat krisis. (Kristin Samah 2018: 228). Multi National Corporation (MNC) ini akan berhadapan dengan aturan pemerintah wajib mencadangkan sebagian labanya untuk imbalan kerja jangka panjang, dan merupakan hambatan dan tantangan kedepan.

Ilustrasi data berikut menggambarkan laba bruto perseroan cenderung stagnan empat tahun terakhir, dan mengindikasi laba bersih menurun, dari tahun 2018 sebesar 9,386 triliun menjadi tahun 2019 sebesar 7,090 triliun (Financial Report, 2019).

Hal ini perlu pengawasan lebih detail, apalagi di era pandemik Covid-19 akan semakin merosot.

Tabel 1.

Perkembangan Imbalan Kerja dan Laba

Bruto PT. Unilever Indonesia, Tbk. 20152019

\begin{tabular}{|c|c|c|c|c|}
\hline TAHUN & $\begin{array}{c}\text { IMBALAN } \\
\text { KERJA }\end{array}$ & PERTUMBUHAN & $\begin{array}{c}\text { LABA } \\
\text { BRUTO }\end{array}$ & PERTUMBUHAN \\
\hline 2015 & $403.002,0$ & & $18.648 .969,0$ & \\
\hline 2016 & $918.211,0$ & 127,8 & $20.459 .096,0$ & 9,7 \\
\hline 2017 & $1.002 .285,0$ & 9,2 & $21.219 .734,0$ & 3,7 \\
\hline 2018 & $709.911,0$ & $(29,2)$ & $21.092 .273,0$ & $(0,6)$ \\
\hline 2019 & $1.047 .616,0$ & 47,6 & $22.028 .693,0$ & 4,4 \\
\hline
\end{tabular}

Sumber : Financial Report Perseroan (20152019) diolah.

Langkah berikutnya rumusan-rumusan masalah ditetapkan sebagai berikut: 
1. Seberapa besar dampak Imbalan Kerja $\left(\mathrm{X}_{1}\right)$ terhadap Laba Bruto PT. Unilever Indonesia, Tbk. (Y) ?

2. Seberapa besar dampak Harga Pokok Produksi $\left(\mathrm{X}_{2}\right)$ terhadap Laba Bruto PT. Unilever Indonesia, Tbk. (Y)?

3. Seberapa besar dampak Imbalan Kerja $\left(X_{1}\right)$ dan Harga Pokok Produksi $\left(\mathrm{X}_{2}\right)$ terhadap Laba Bruto PT. Unilever Indonesia, Tbk. (Y)?

Penetapan tujuan penelitian ini selaras dengan rumusan-rumusan masalah sebelumnya, yaitu:

1. Untuk membahas besarnya dampak pengaruh Imbalan Kerja terhadap Laba Bruto PT. Unilever Indonesia, Tbk.

2. Untuk mendiskusikan seberapa besar dampak pengaruh Harga Pokok Produksi terhadap Laba Bruto PT. Unilever Indonesia, Tbk.

3. Untuk menganalisis besarnya pengaruh Imbalan Kerja dan Harga Pokok Produksi terhadap Laba Bruto PT. Unilever Indonesia, Tbk.

Merujuk pada tujuan tersebut, maka penelitian ini diharapkan dapat berguna bagi para pihak terkait ( stake holders) diantaranya:

1. Secara ekonomi dan bisnis diharapkan bemanfaat seluruh industri personal care dan rumah tangga di Indonesia,memiliki strategi manajemen keuangan yang dinamis, dan memberikan jaminan kesejahteraan SDM

2. Secara Akademik yaitu menjadi bahan masukkan bagi peneliti berikutnya, dibidang Akuntansi

3. Bagi penulis adalah dosen professional bersertifikasi, sebagai pemacu semangat penelitian yang merupakan bagian tak terpisahkan dari Tri Dharma Perguruan Tinggi.

\section{KAJIAN TEORITIS}

Suatu dasar untuk penelitian ilmiah mulai dari pengumpulan data, merumuskan dan menganalisis permasalahan harus berdasarkan literatur atau buku-buku dan karya ilmiah yang berkaitan dengan kegiatan penelitian yang dilaksanakan.

Penelitian ini menggunakan grand theory Akuntansi yang dilengkapi data-data dapat diunduh (download) dari berbagai media daring,literatur, opini, FGD (Focus Group Disccussion) dan dari sumber lainnya.

\section{Akuntansi}

Berasal dari kata accountingberarti sebuah kegiatan mengidentifikasi, mengklasifikasi,mencatat, mengolah, ataupun menyajikan data yang berhubungan dengan transaksi finansialpada akhirnya dapat dipergunakan untuk pengambian keputusan dalam organisasi.

Dengan demikian akuntansi dapat didefinisikan sebagai bagian seni (art) dalam mengukur, berkomunikasi, dan menjabarkanpraktik aktivitas finansial atau keuangan (Para ahli :2018).

MenurutMulyadi (2012) sistem akuntansi adalah organisasi formulir, berupa catatan dan laporan yang dikoordinasi sedemikian rupa, sehingga dapat menyediakan informasi finansial atau keuangan yang dibutuhkan oleh manajemen guna memudahkan pengelolaan perusahaan. Dengan demikian akuntansi difungsikan sebagai alat mencatat dan menyajikan laporan keuangan untuk memudahkan manajemen dalam pengelolaan dan menjalankan aktivitas organisasi atau perusahaan.

Pada penghujung kegiatan akuntansi akan tercipta bentuk laporan keuangan yang berupa Neraca dan Laba Rugi yang sangat penting bagi dunia usaha terutama yang sudah mencatatkan sahamnya di bursa efek

\section{Imbalan Kerja}

Imbalan kerja merupakan hak karyawan atau pegawai suatu perusahaan terdiri dari imbalan kerja jangka pendek, 
pesangon pemutusan kontrak kerja, imbalan pasca kerja dan imbalan kerja jangka panjang lainnya (Taufik Hidayat 2013 : 2-3)

Menurut Buku Laporan Tahunan PT. Unilever Indonesia Tbk. (2019, hal.5/15), imbalan kerja terdiri dari :

Imbalan jangka pendek, yaitu imbalan kerja yang diakui pada saat terutang kepada pegawai atau karyawan. Pengakuan beban atas bonus sebagai liabilitas oleh perseroan, dengan memperhitungkan laba yang tersedia baik bagi karyawan-karyawan berprestasi dan para pemegang saham dengan kondisional penyesuaian tertentu.

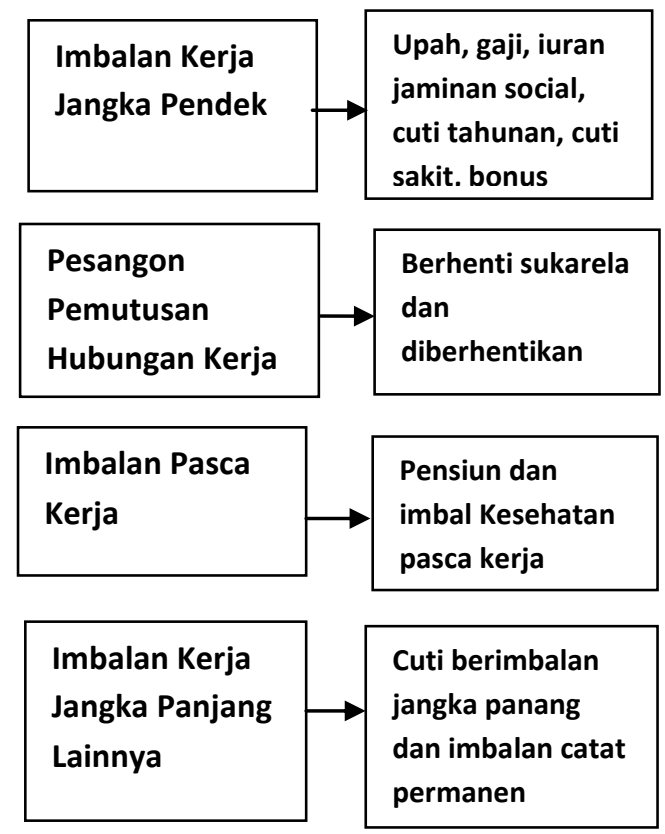

Gambar.1 Ruang Lingkup Imbalan Kerja

(Sumber Taufik Hidayat)

Imbalan pensiun, program pensiun imbalan pasti dan iuran pasti yang dimiliki oleh Perseroan. Program ini menetapkan imbalan yang jumlahnya akan diterima karyawan apabila saatnya pensiun, yang ditentukan oleh suatu faktor seperti umur, masa kerja serta jumlah kompensasi imbalannya.

\section{Harga Pokok Produksi}

Supriyono (2013), menjabarkan bahwa Harga Pokok Produksi adalah jumlah dana atau uang yang akan dibayarkan untuk dapat memiliki produk yaitu barang atau jasa yang dibutuhkan perusahaan, sebagai sarana untuk menghasilkan profit atau keuntungan.

Harga Pokok Produksi, yaitu saldo awal bahan baku ditambah pembelian bahan baku dikurangi saldo akhir bahan baku merupakan jumlah bahan yang digunakan untuk proses produksi, ditambah biaya tenaga kerja langsung dan biaya-biaya overhead pabrik merupakan jumlah biaya produksi, ditambah saldo awal barang dalam proses dikurangi saldo akhir barang dalam proses (Laporan tahunan PT. Unilever Indonesia, 2019 : 5/58). Metode perhitungan Harga Pokok Produksi masal dan sekala besar biasanya menerapkan sistem full costing, menurut V. Wiratna Sujarweni (2019:29) perhitungan Harga Pokok Produksi dengan membebankan semua biaya produksi baik variabel maupun biaya tetap, pada produk yang dihasilkan, yang disebut juga Harga Pokok Produksi konvensional.

\section{Laba Bruto}

Laba yang diperoleh dari jumlah penjualan setelah potongan harga dan retur penjualan dikurangi harga pokok penjualan.

Menurut Kasmir (2011:303), Laba bruto yang biasa diartikan sebagai gross profityaitulaba yang diperoleh sebelum dikurangi bebanbeban perusahaan yang berupa biaya pokok penjualan.

Definisi lain tentang laba kotor, yaitu laba bruto berupa pendapatan dari penjualan dikurang biaya pertanggung jawaban atas produksi barang dan jasa, belum dikurangi biaya untuk gaji administrasi umum, beban pemasaran, pembayaran bunga pinjaman bank dan pajak (accurate.id.akuntansi :2019) Laba bruto (Gross profit) juga merupakan pendapatan setelah dikurangi seluruh biaya untuk pembuatan produk meliputi bahan 
baku, tenaga kerja produksi dan biaya overhead pabrik.Maka dalam sebuahbisnis laba kotor dapat digunakan sebagai dasar perhitungan mengenai jumlah sisa pendapatan yang dapat dipakai untuk menyelesaikan beban perusahaan berupa biaya-biaya setelah produk selesai dibuat (Karunia Saputra, 2019)

\section{Kerangka Berfikir Penelitian}

John Ihalauw (2014: 19), mengatakan landasan berfikir pada sebuah penelitian yang memiliki makna, berupa paradigma penelitian yang mampu menunjukkan alur dan arah terhadap metode dan gagasan dalam penelitian tersebut.

Kerangka pemikiran dalam suatu penelitian menggambarkan novelty, atau urut-urutan cerita mengenai faktor-faktor apa saja yang mempengaruhi variabel terikat dalam modelmodel penelitian.

Kerangka berfikir penelitian ini mencerminkan hubungan antara variabelvariabel independen Imbalan Kerja dan Harga Pokok Produksi terhadap variabel terikat Laba Bruto PT.Unilever Indonesia, Tbk.

Maka model kerangka pemikiran penelitian ini dapat digambarkan sebagai berikut :

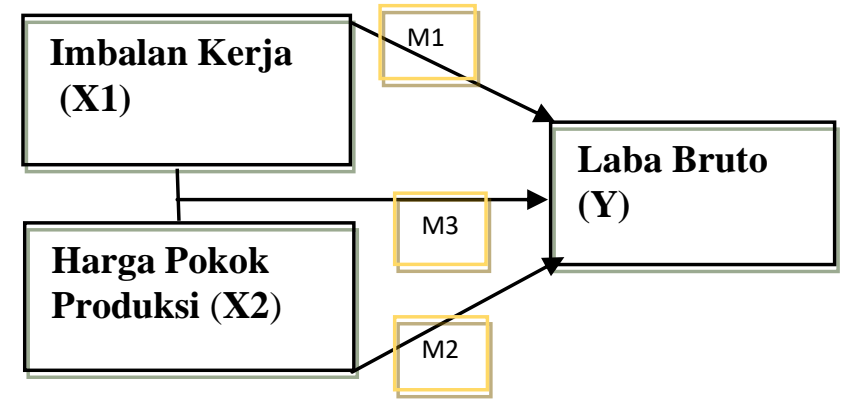

Gambar. 2 Kerangka Berfikir

Novelti gambar 2 antara lain :

Model 1, menunjukkan hubungan antara variabel bebas Imbalan keja terhadap variabel tak bebas Laba bruto perusahaan.

Model 2, mencerminkan hubungan antara variabel independen Harga pokok produksi terhadap variabel dependen Laba bruto perusahaan.

Model 3, menggambarkan hubungan variabel-variabel bebas Imbalan kerja dan
Harga pokok produksi secara besama-sama terhadap variabel terikat Laba bruto perseroan.

\section{Hipotesis Penelitian}

Penelitian ini jenis ekspalanatori, yaitu penelitian tentang hubungan kausal antara variabel-varibel independen dengan variabel dependen dalam suatu model, dan menggunakan hipotesis yang selanjutnya dianalisis, dibahas, diuji dan dibuktikan kebenarannya.

Pendapat ahli statistik Sugiyono (2017: 39) menerangkan hipotesis suatu penelitian dapat diuji pembuktiannya melalui kalkulasi perhitungan statistik.

Menurut Burhan Bungin (2013:92) ada beberapa sifat hipotesis yang harus dicermati diantaranya:

a. Hipotesis harus menunjukkan adanya hubungan teori serta masalah yang diteliti

b. Setiap hipotesis merupakan kemungkinan jawaban dari masalah yang diteliti

c. Hipotesis tersebut harus dapat diuji untuk menetapkan hipotesis mana yang paling besar kemungkinannya dan didukung data-data empiris

Maka atas dasar teori-teori tersebut, penelitian ini mengemukakan hipotesishipotesis sebagai berikut:

H1: Diduga ada dampak signifikan antara Imbalan Karyawan terhadap Laba Bruto PT. Unilever Indonesia, Tbk.

H2: Diduga ada dampak signifikan antara Harga Pokok Produksi PT. Unilever Indonesia,Tbk.

H3: Diduga terdapat dampak signifikan antara Imbalan Karyawan dan Harga Pokok Produksi terhadap Laba Bruto PT. Unilever Indonesia, Tbk.

\section{METODE PENELITIAN}

Metode penelitian dalam riset ini terdiri dari berapa langkah mulai kegiatan persiapan penelitian, pengumpulan data sekunder, pengolahan dan pembahasan data sebagai pengukuran analisis, serta hasil laporan 
penelitian hingga dikemukakan simpulan dan saran-saran.

\section{Desain Penelitian}

Desain penelitain kuantitatif merupakan semua proses diawali penentuan judul, latar belakang, pokok-pokok permasalahan, kegunaan dan tujuan, penetapan indikator variabel-variabel penelitian, sumber data, pengukuran dan analisis yang dipergunakan, sehingga merupakan suatu proses yang diperlukan dalam perencanaan dan pelaksanaan suatu penelitian.

Data sekunder time series di-download dari publikasi daring Laporan tahunan PT. Unilever Indonesia, Tbk. selama 12 tahun sejak 2008- 2019, dengan demikian dapat ditentukan $\mathrm{n}=12$.

Waktu Penelitian selama 4 (empat bulan) dari Februari hingga Mei 2020

\section{Variabel Penelitian dan Definisi Operasional Variabel}

\section{Variabel Penelitian}

Konsep ini merupakan pengoperasionalan variabel-variabel yang digunakan dalam penelitian dan dapat dijelaskan melalui indikator-indikator parameternya.

Penjelasan variabel-variabel ini berupa hubungan-hubungan antara lain:

Variabel memengaruhi yaitu Imbalan Kerja dengan huruf $\left(\mathrm{X}_{1}\right)$,

Harga Pokok Produksi dengan lambang $\left(\mathrm{X}_{2}\right)$

Variabel dipengaruhi yaitu Laba Bruto dengan huruf $(\mathrm{Y})$

\section{Batasan Operasional Variabel}

Operasional variabel dalam penelitian ini didefinisikan berupa batasan-batasan untuk menghindari kesalahan dalam pengambilan keputusan.

Klasifikasi terhadap variabel-variabel penelitian dibuat dan definisikan agar pengambilan keputusan bisa dilakukan secara tepat dan akurat (Sumadi Suryabrata 2016 : 48).

Definisi operasional pada penelitian ini adalah :

Variabel independen $\left(\mathrm{X}_{1}\right)$ disebutkan sebagai Imbalan Kerja(employee benefits) adalah imbalankeseluruhan yang diberikan suatu entitas dalam pertukaran atas jasayang diberikan pekerja atau untuk pemutusan kontrak kerja. (PSAK 24: 2010).

Variabel independen lainya berlambang $\left(\mathrm{X}_{2}\right)$ sebagai Harga Pokok Produksi, biaya yang dikeluarkan untuk produksi diluar beban pemasaran dan administrasi umum (Financial Report PT. Unilever Indonesia 2019).

Dalam penelitian ini variabel terkait adalah : Variabel dependen yaitu Laba Bruto diberi lambang (Y), berupa selisih antara penjualan neto dengan harga pokok penjualan. (Financial Report Perseroan 2019).

\section{Populasi dan Sampel}

Algifari (2015 : 6) menyebutkan populasi semua anggota obyek yang digunakan sebagai data untuk diteliti membutuhkan waktu lama dan membutuhkan dana besar. Sedangkan sampel merupakan kumpulan dari sebagian obyek yang diteliti, sehingga sampel mewakili populasinya.

Burhan Bungin (2013: 101) mengatakan bahwa populasi merupakan sekumpulan, serumpun obyek yang akhirnya menjadi sasaran dari penelitian itu sendiri. Dengan demikian populasi penelitian dapat didefinisikan menjadi universum atau keseluruhan dari obyek-obyek yang menjadi sumber penelitian.

Sedangkan sampel dapat dikatakan merupakan bagian obyek yang diteliti dan mewakili populasinya.

Populasi dan sampel pada penelitian ini sama berupa seluruh data yang diteliti yaitu imbalan kerja, harga pokok produksi serta 
laba bruto PT. Unilever Indonesia Tbk. pada periode $2008-2019$.

\section{Metode pengambilan data}

Pengambilan serta pengumpulan data sekunder melalui pemotretan, perekaman data-data Annual Report PT. Unilever Indonesia, Tbk yang diunduh dari Bursa Efek Indonesia (BEI) secara online.

Sehingga didapat jenis data runtut waktu (time series) selama 12 tahun, terhitung sejak tahun 2008 hingga tahun 2019.

\section{Analisis data penelitian}

Metode analisis yang digunakan untuk pengujian data-data penelitian ini sebagai berikut :

\section{Uji Asumsi Klasik}

Penaksiran uji asumsi klasik ini juga disebut BLUE Test (best linear unbiased estimator), untuk mendapatkan data yang linier. Suliyanto ( $2011:$ 69) SPSS digunakan untuk melakukan uji BLUE, dengan langkahlangkah sebagai berikut:

a. Uji Normalitas, metode One-Sample Kolmogorov-Smirnov Test. Metode uji ini mengatakan jika hasil Asymp. Sig. (2-tailed) $>0,05$ maka data pada model jenis penelitian ini memiliki distribusi normal.

b. Uji Multikolinieritas

Uji Multikolinier Summary, dengan membandingkan hasil R-Square simultan dengan R- square modelmodel parsial, dan probabilitas $\mathrm{t}$ semua siginifikan.Jika $\mathrm{R}^{2}$ Simultan > dari semua $R^{2}$ parsial, maka model yang diteliti tidak terdapat gejala multikolinier.

c. Uji Heteroskedastisitas, melalui Uji Glejser

Jika Dependent Variabel Abs Res. hasil probabilitas Sig. > dengan $\mathrm{p}$ value $>\alpha=0,05$, maka model penelitian disimpulkan tidak terdapat gejala heteroskedastisitas.

d. Uji Autokorelasi, dengan uji Runs Test Jika hasil hitung statistik Asymp. Sig. $(2$-tiled $)>$ dari $\mathrm{p}_{\text {value }}>\alpha$ (alpha) $=$
0,05 maka model tidak terdapat autokorelasi.

\section{Uji Korelasi}

Uji Korelasi sederhana (Bevariate Correlation) untuk mengetahui kekuatan hubungan parsial variabel bebas dengan variabel terikat.

Uji Korelasi berganda (Multiple Correlation) untuk analisis kekuatan hubungan secara simultan variabel independen dengan variabel dependen.

Uji keterhubungan tersebut dalam perhitungan statistik ditunjukkan oleh besarnya angka $R$.

\section{Uji Koefisien Determinasi $\left(\mathrm{R}^{2}\right)$}

$\mathrm{R}$ Square, menunjukkan parameter berapa besar pengaruh variabel bebas terhadap variabel dependen terikat baik sendiri-sendiri ataupun simultan dalam suatu penelitian.

\section{Uji Regresi}

Uji regresi linier digunakan dalam penelitian ini, yaitu :

a. Uji regresi linier sederhana, dengan model $\mathrm{Y}=\mathrm{f}(\mathrm{X})$

b. Uji regresi linier berganda atau diwakili oleh model $\mathrm{Y}=$ $\mathrm{f}\left(\mathrm{X}_{1}, \mathrm{X}_{2} \ldots \mathrm{Xn}\right)$

Apabila $\mathrm{R}$ Square baik parsial maupun simultan, hasilnya > $50 \%$, maka model tersebut dapat dipakai sebagai alat peramalan dimasa yang akan datang (Yuyun Wirasasmita, 2013: 2).

\section{Uji Hipotesis}

\section{Uji t}

Uji t digunakan untuk hipotesis model parsial. Jikalau hasil $\mathrm{t}_{\text {hitung }}>\mathrm{t}_{\text {tabel, }}$ maka ada pengaruh antara $X_{1}$ terhadap $Y$ atau...... $X_{n}$ terhadap $Y_{n}$

\section{Model 1}

$\mathrm{H}_{0}$ : $\mathrm{b}_{1},=0$, Koefisien regresi faktor $\mathrm{b}_{1}$, sama dengan nol, artinya tidak ada pengaruh antara Imbalan Kerja $\left(\mathrm{X}_{1}\right)$ terhadap Laba Bruto PT. Unilever Indonesia, Tbk. (Y)

Ha $: b_{1}$, tidak $=0$, Koefisien regresi faktor $b_{1}$ tidak sama dengan nol, artinya ada dampak 
antara Imbalan Kerja $\mathrm{X}_{1}$ ) terhadap Laba

Bruto PT. Unilever Indonesia, Tbk. (Y)

Model 2

$\mathrm{H}_{0}: \mathrm{b}_{2,}=0$, Koefisien regresi faktorb ${ }_{2}$ sama dengan nol, artinya tidak ada pengaruh antara Harga Pokok Produksi $\left(\mathrm{X}_{2}\right)$ terhadap Laba Bruto PT. Unilever Indonesia, Tbk. (Y) Ha : $b_{1}$, tidak $=0$, Koefisien regresi faktor $b_{2}$ tidak sama dengan nol, artinya ada dampak antara antara Harga Pokok Produksi $\left(\mathrm{X}_{2}\right)$ terhadap Laba Bruto PT. Unilever Indonesia, Tbk. (Y)

\section{Uji F}

Uji hipotesis secara bersama-sama untuk model yang memiliki variabel bebas lebih dari satu, jika $F$ hitung $>F$ tabel, maka ada pengaruh antara $X_{1}, X_{2 \ldots} X_{n}$ terhadap $Y_{n}$

\section{Model 3}

$\mathrm{H}_{0}$ : $\mathrm{b}_{1}, \mathrm{~b}_{2}=0$, Koefisien regresi faktor $\mathrm{b}_{1}, \mathrm{~b}_{2}$ sama dengan nol, artinya tidak ada pengaruh secara bersama-sama antar Imbalan Kerja $\left(\mathrm{X}_{1}\right)$ dan Harga Pokok Produksi $\left(\mathrm{X}_{2}\right)$ terhadap Laba Bruto PT. Unilever Indonesia, Tbk. (Y)

Ha : $b_{1}, b_{2}$ tidak $=0$, Koefisien regresi faktor $b_{1}, b_{2}$ tidak sama dengan nol, artinya ada pengaruh secara simultan antara Imbalan Kerja $\left(\mathrm{X}_{1}\right)$ dan Harga Pokok Produksi $\left(\mathrm{X}_{2}\right)$ terhadap Laba Bruto PT. Unilever Indonesia, Tbk. (Y)

\section{ANALISIS DAN PEMBAHASAN}

\section{Deskripsi Objek Penelitian}

Analisis, diskusi dan pembahasan pada penelitian ini mengenai Imbalan Kerja , dan Harga Pokok Produksi diduga memiliki pengaruh signifikan terhadap Total Biaya Produksi pada perusahaan multi nasional corporation PT. Unilever Indonesia, Tbk. Dan tabel dibawah ini menunjukkan data sekunder yang akan dianalisis dan diteliti :

Tabel 2.Imbalan Kerja , Harga Pokok

Produksi dan Laba Bruto (dalam juta) PT. Unilever Indonesia Tbk.

\section{Periode 2008 - 2019}

\begin{tabular}{cccr}
\hline Tahun & Imbal Kerja & HPP & \multicolumn{1}{c}{ Laba Bruto } \\
\hline $\mathbf{2 0 0 8}$ & $33.472,0$ & $7.908 .861,0$ & $7.631 .137,0$ \\
$\mathbf{2 0 0 9}$ & $51.630,0$ & $8.970 .106,0$ & $9.041 .741,0$ \\
$\mathbf{2 0 1 0}$ & $71.886,0$ & $9.297 .123,0$ & $10.204 .965,0$ \\
$\mathbf{2 0 1 1}$ & $122.093,0$ & $11.236 .143,0$ & $12.006 .413,0$ \\
$\mathbf{2 0 1 2}$ & $158.303,0$ & $12.840 .344,0$ & $13.889 .126,0$ \\
$\mathbf{2 0 1 3}$ & $104.417,0$ & $14.171 .222,0$ & $15.778 .488,0$ \\
$\mathbf{2 0 1 4}$ & $116.888,0$ & $16.981 .449,0$ & $17.099 .121,0$ \\
$\mathbf{2 0 1 5}$ & $403.002,0$ & $17.142 .080,0$ & $18.648 .969,0$ \\
$\mathbf{2 0 1 6}$ & $918.211,0$ & $17.905 .268,0$ & $20.459 .096,0$ \\
$\mathbf{2 0 1 7}$ & $1.002 .285,0$ & $18.297 .684,0$ & $21.219 .734,0$ \\
$\mathbf{2 0 1 8}$ & $709.911,0$ & $19.067 .235,0$ & $21.092 .273,0$ \\
$\mathbf{2 0 1 9}$ & $1.047 .616,0$ & $19.989 .874,0$ & $22.028 .693,0$ \\
\hline
\end{tabular}

Sumber : Laporan Tahunan Perseroan (2008 2019, diolah)

Sudarsono (2013:2), untuk mendapatkan data yang tepat dan presisi, maka sebelum dikalkulasi secara statistik, data harus diubah menjadi bentuk Ln.

\section{LAPORAN HASIL PENELITIAN}

\section{Deskripsi Objek Penelitian}

Analisisi pembahasan pada penelitian ini mengenai Imbalan Kerja , dan Harga Pokok Produksi diduga memiliki pengaruh signifikan terhadap Total Biaya Produksi pada perusahaan multi nasional corporation PT. Unilever Indonesia, Tbk..Tabel dibawah ini menunjukkan data sekunder yang akan dianalisis, yaitu:

\section{Analisis dan Interpretasi}

\section{Uji Asumsi Klasik}

\section{Uji Normalitas}

Uji normalitas suatu penelitian dapat diketahui melalui Uji Kologorov Smirnov (Suliyanto 2011: 75). 
Tabel A.

Uji Kolmogorov-Smirnov

One-Sample Kolmogorov-Smirnov Test

\begin{tabular}{|c|c|c|}
\hline & & $\begin{array}{c}\text { Standardized } \\
\text { Residual }\end{array}$ \\
\hline \multicolumn{2}{|l|}{$\mathrm{N}$} & 12 \\
\hline Normal & Mean &, 0000000 \\
\hline \multirow[t]{2}{*}{ Parameters $^{\mathrm{a}, \mathrm{b}}$} & Std. & 2015240 \\
\hline & Deviation & (2) \\
\hline Most Extreme & Absolute & , 150 \\
\hline \multirow[t]{2}{*}{ Differences } & Positive & , 150 \\
\hline & Negative &,- 140 \\
\hline \multicolumn{2}{|l|}{ Test Statistic } & , 150 \\
\hline \multicolumn{2}{|c|}{ Asymp. Sig. (2-tailed) } &, $200^{c, d}$ \\
\hline
\end{tabular}

a. Test distribution is Normal.

b. Calculated from data.

c. Lilliefors Significance Correction.

d. This is a lower bound of the true significance.

Kesimpulan model berdistribusi normal dengan hasil $0,200>$ alpha 0,05

\section{Uji Multikolinieritas}

Hasil $\mathrm{R}^{2}$ Simultan $0,991,>\mathrm{R}^{2}$ model $1=$ $0,849>, \mathrm{R}^{2}$ model $2=0,987$ maka model penelitian dengan data yang digunakan tidak mengalami gejala multikolinier.

\section{Uji Heteroskedastisitas}

Tabel B.Uji Glejser

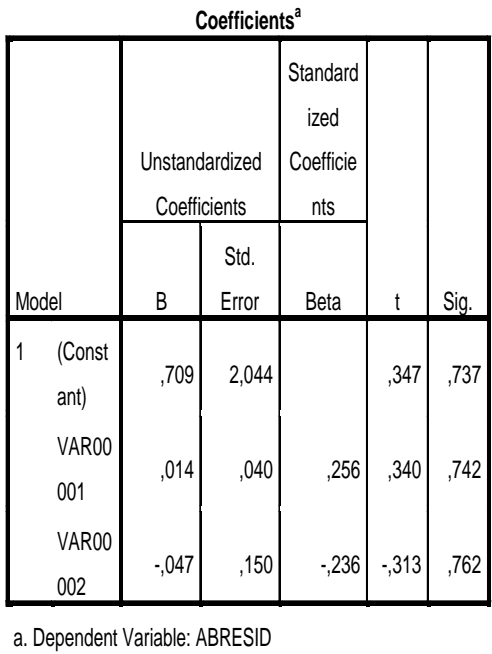

Dependent Variabel Abs Res. Diperoleh hasil probabilitas Sig. 0,742 dan

$0,762>$ masing-masing > dari $\mathrm{p}_{\text {value }} \alpha=0,05$, maka disimpulkan model penelitian ini tidak ada gejala heteroskedastisitas.

\section{Uji Autokorelasi}

Tabel C.

Runs Test

\begin{tabular}{|l|r|}
\hline \multicolumn{2}{|c|}{ Runs Test } \\
\hline & $\begin{array}{c}\text { Unstandardized } \\
\text { Residual }\end{array}$ \\
\hline Test Value $^{\mathrm{a}}$ &, 02532 \\
Cases < Test Value & 6 \\
Cases >= Test Value & 6 \\
Total Cases & 12 \\
Number of Runs & 5 \\
Z &,- 908 \\
Asymp. Sig. (2-tailed) &, 364 \\
\hline
\end{tabular}

a. Median

Hasil symp. Sig. (2-tiled) $0,364>$ dari $\mathrm{p}_{\text {value }}>$ $\alpha=0,05$ maka model ini disimpulkan tidak ada autokorelasi.

Pembahasan untuk diskusi Model $1, Y=f$ $\left(\mathrm{X}_{1}\right)$

Melalui Uji Korelasi Sederhana, maka dapat diuji seberapa besar hubungan antara $X_{1}$ terhadap $\mathrm{Y}$, yaitu korelasi $\mathrm{R}=0,921$. 
Menyatakan hasil analisis terdapat hubungan positif dan sangat kuat.

Tabel 3.

.Imbal Kerja $\left(\mathbf{X}_{1}\right)$ terhadap Laba Bersih

(Y)

\begin{tabular}{|l|c|r|r|c|}
\hline Model & $\mathrm{R}$ & $\mathrm{R}$ Square & $\begin{array}{c}\text { Adjusted R } \\
\text { Square }\end{array}$ & $\begin{array}{c}\text { Std. Error of the } \\
\text { Estimate }\end{array}$ \\
\hline 1 &, $921^{\mathrm{a}}$ &, 849 &, 834 &, 14869 \\
\hline
\end{tabular}

a. Predictors: (Constant), VAR1 Imbalan Kerja

Analisis untuk menentukan besarnya pengaruh $\mathrm{X}_{1}$ terhadap $\mathrm{Y}$, tabel diatas menjelaskan $\mathrm{R}$ Square $=0,849$ artinya besarnya pengaruh antara

Imbal Kerja $\left(\mathrm{X}_{1}\right)$ terhadap Laba Bersih $(\mathrm{Y})=$ $84,90 \%$ dan sisanya dipengaruhi faktor lain yang tidak termasuk dalam penelitian ini.

Tabel 4.

Regresi Model $\mathrm{Y}=\mathrm{f}\left(\mathrm{X}_{1}\right)$

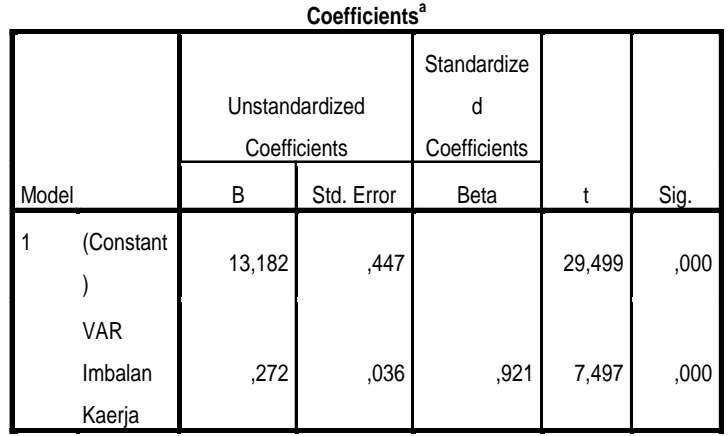

a. Dependent Variable: VAR3 Laba Bruto

Persamaan Regresi Linier:

$\mathrm{Y}=\mathrm{a}+\mathrm{b}_{1} \mathrm{X}_{1}+\varepsilon$

$\mathrm{Y}=\mathrm{Laba}$

$\mathrm{a}=$ Konstan

$\mathrm{X}_{1}=$ Imbalan

$\varepsilon=$ Error Standard

Prediksi

$\hat{Y}=13,182+0,272 \mathrm{X}_{1}$

Atas dasar tabel 4, persamaan regresi ini menerangkan ada dampak positif antara Constant (C), Imbalan Kerja ( $\left.\mathrm{X}_{1}\right)$ terhadap prediksi Laba Bruto $\hat{Y}$ hasilnya memiliki hubungan searah.

Interpretasi dari model ini, apabila $\mathrm{X}_{1}$ adalah $=0$, maka prediksi nilai $\hat{Y}$ akan berubah seesar konstannya yaitu 13,182 satuan. Jika konstan $=0$, maka $\mathrm{Y}^{\wedge}$ akan berubah menjadi $0,272 *\left(\mathrm{X}_{1}\right)$, diasumsikan variabel-variabel lain tidak ada perubahan.

Uji hipotesis secara individu mendapatkan hasil sebagai berikut $\mathrm{t}$ tabel didapatadalah sebesar $: \mathrm{n}=12, \mathrm{k}=1, \alpha=0,05$, nilai $\mathrm{t}$ two tilled $\mathrm{t}_{\text {tabel( } \mathrm{n}-\mathrm{k}-1)}=2,228 \mathrm{t}_{\text {hitung }} 7,497>$ $\mathrm{t}$ tabel. 2,228. Model ini singnifikan karena tingkat sig. $0,00<p$ value 0,05 artinya Model 2 ini dapat disimpulkan, Ho ditolak $\mathrm{Ha}$ diterima, yaitu terdapat pengaruh atau dampak positif dan signifikan antara Imbalan Kerja $\left(\mathrm{X}_{1}\right)$ terhadap Laba Bruto $(\mathrm{Y})$

\section{Pembahasan untuk Diskusi Model 2, $Y=\mathbf{f}$} $\left(\mathbf{X}_{2}\right)$

Pembahasan model 2 ini berdasarkan hasil perhitungan statistik menggunakan SPSS-versi 22 adalah :

Model ini menggunakan uji korelasi linier sederhana.

Tabel 5.

Korelasi Harga Pokok Produksi dan Laba Bruto.

Model Summary

\begin{tabular}{|l|r|r|r|c|}
\hline Model & \multicolumn{1}{|c|}{$\mathrm{R}$} & $\mathrm{R}$ Square & \multicolumn{1}{c|}{$\begin{array}{c}\text { Adjusted R } \\
\text { Square }\end{array}$} & $\begin{array}{c}\text { Std. Error of the } \\
\text { Estimate }\end{array}$ \\
\hline 1 &, $993^{\mathrm{a}}$ &, 987 &, 985 &, 04402 \\
\hline
\end{tabular}

a. Predictors: (Constant), VAR2 Harga Pokok Produksi

Korelasi yang ditujukkan oleh tabel 5, yaitu $\mathrm{X}_{2}$ terhadap $\mathrm{Y}$, dengan simbol $\mathrm{R}=0,993$ menerangkan model ini memiliki korelasi antara variabel independen terhadap variabel dependen positif dan sangat kuat.

Besarnya pengaruh antara variabel bebas terhadap variabel terikat, ditunjukkan oleh besarnya angka koefisien determinasi. 
Dari tabel 5 ditampilkan hasil koefisien determinasi sebesar RSquare $=0,987$, mengartikan besarnya pengaruh Harga Pokok Produksi $\left(\mathrm{X}_{2}\right)$ terhadap Laba Bruto $(\mathrm{Y})=$ $98,70 \%$, sisanya dipengaruhi oleh variabel lain diluar penelian ini.

Hasil uji regresi model 2 yaitu $\mathrm{X}_{2}$ (Harga Pokok Produksi) terhadap Y (Laba Bruto) yang dterangkan oleh tabel berikut:

\section{Tabel 6.}

Persamaan Regresi $\mathrm{Y}=\mathrm{f}\left(\mathrm{X}_{2}\right)$

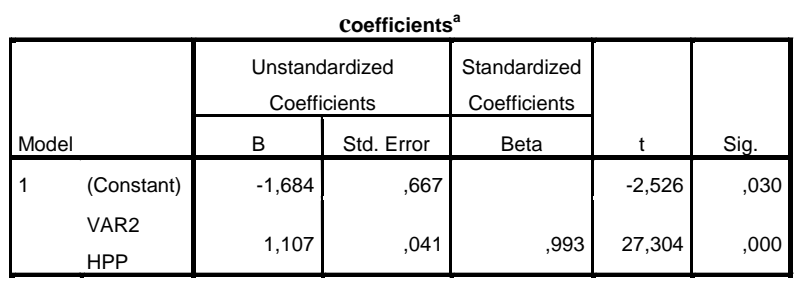

a. Dependent Variable: VAR3 Laba Bruto

Persamaan : $\mathrm{Y}=\mathrm{a}+\mathrm{b}_{2} \mathrm{X}_{2}+\varepsilon$

$\mathrm{Y}=$ Laba Bruto

$\mathrm{a}=$ Konstan

$\mathrm{X}_{2}=$ Harga Pokok Produksi

$\varepsilon=$ Error Standard

Tabel 6 menunjukkan bahwa persamaan regresi model ini ada pengaruh negatifantara nilai konstan (C), Harga Pokok Produksisi $\left(\mathrm{X}_{2}\right)$ positif terhadap prediksi perubahan Laba Bersih $(\hat{Y})$. Interpretasi persamaan ini, jika $\mathrm{X}_{2}=0$, maka nilai $\hat{Y}$ akan menjadi minus atau turun $-1,684$. Jika konstan $=0$, maka nilai prediksi Total Biaya Produksi $\hat{Y}$ berubah menjadi $1,107 *\left(\mathrm{X}_{2}\right)$

Tabel 6 menunjukkan juga hasil uji hipotesis parsial sebagai berikut :

$\mathrm{t}_{\text {hitung }}=27,304, \mathrm{n}=12, \mathrm{k}=1, \alpha=0,05$, nilsi t two tilled $\mathrm{t}$ tabel( $\mathrm{n}-\mathrm{k}-1)=2,228 \mathrm{t}_{\text {hitung }}>\mathrm{t}$ tabel. Hasil uji sig. $0,00<$ p value 0,05 memiliki arti bahwa model ini signifikan. Model 2 dapat disimpulkan yaitu, Ho ditolak Ha diterima, yaitu secara parsial ada pengaruh positif, signifikan antara Harga Pokok Produksi $\left(\mathrm{X}_{2}\right)$ terhadap Laba Bruto PT. Unilever Indonesia, Tbk.(Y).

Pembahasan untuk diskusi Model 3, Y = f $\left(\mathbf{X}_{1}, \mathbf{X}_{2}\right)$

Menggunakan program statistik, maka hasil analisis model simultan ini adalah :
Tabel 7.

Korelasi $\mathrm{X}_{1}$ dan $\mathrm{X}_{2}$ terhadapY

Model Summary

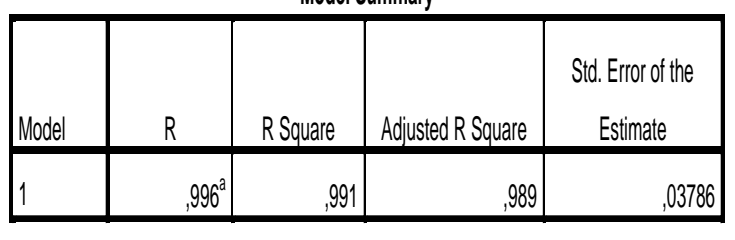

a. Predictors: (Constant), VAR2 Harga Pokok Produksi, VAR1 Imbalan Kerja

Uji korelasi berganda pada model simultan $\mathrm{X}_{1}$ dan $\mathrm{X}_{2}$ terhadap $\mathrm{Y}$, diperlihatkan oleh tabel 7, angka $R=0,996$ mengartikan hubungan positif dan sangat kuat.

Angka R Square pada tabel diatas, merupakan besaran pengaruh antara variabelvariabel bebas dengan variabel terikat secara simultan.

Data yang diperlihatkan oleh tabel 7, yaitu $\mathrm{R}$ Square $=0,991$, menerangkan besarnya pengaruh antara variabel Imbalan Kerja $\left(\mathrm{X}_{1}\right)$ dan Harga Pokok Produksi $\left(\mathrm{X}_{2}\right)$ terhadap Laba Bruto PT.Unilever Indonesia, Tbk. $(\mathrm{Y})=99,10 \%$ dan sisanya dipengaruhi oleh faktor - faktor lain diluar penelitian ini.

Hasil analisis menggunakan program SPSS-22 disjikan oleh tabel berikut ini :

Tabel 8.

Persamaan Regresi $Y=f\left(X_{1}, X_{2}\right)$

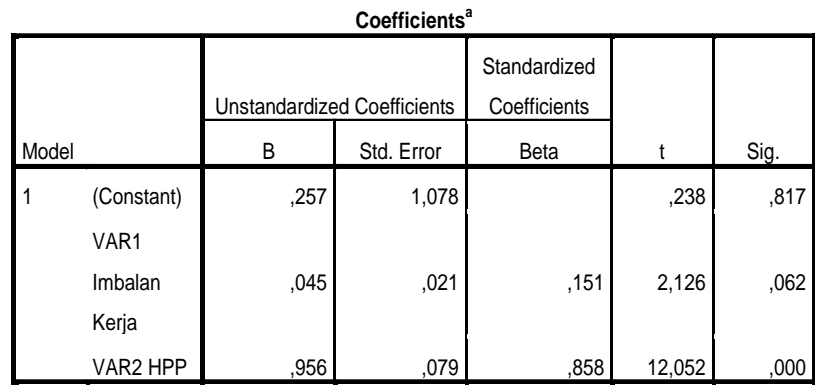

a. Dependent Variable: VAR3 Laba Bruto

Persamaan : $\mathrm{Y}=\mathrm{a}+\mathrm{b}_{1} \mathrm{X}_{1}+\mathrm{b}_{2} \mathrm{X}_{2}+\varepsilon$

$\mathrm{Y}=$ Laba Bruto

$\mathrm{a}=$ konstan

$\mathrm{X}_{1}=$ Imbalan Kerja 
$\varepsilon=$ Standar eror

$\mathrm{X}_{2}=$ Harga Pokok Produksi

$\widehat{Y}=0,257+0,450 \mathrm{X}_{1}+0,956 \mathrm{X}_{2}$

Persamaan regresi pada tabel 8, nilai konstan (C), Imbalan Kerja $\left(\mathrm{X}_{1}\right)$, dan Harga Pokok Produksi $\left(\mathrm{X}_{2}\right)$ searah terhadap prediksi Laba Bruto $(\hat{Y})$.

Model regresi berganda dapat diinterpretasikan, apabila $\left(\mathrm{X}_{1}\right) \operatorname{dan}\left(\mathrm{X}_{2}\right)=0$, maka nilai $\mathrm{Y}^{\wedge}$ akan berubah sama sebesar konstannya yaitu 0,257.Dan bila konstan dan , $\left(\mathrm{X}_{2}\right)=0$ maka $\left(\mathrm{Y}^{\wedge}\right)$ akan berubah $=0,450 *$ $\left(\mathrm{X}_{1}\right)$. Namun jika konstanta dan $\left(\mathrm{X}_{1}\right)=0$, maka $\left(\mathrm{Y}^{\wedge}\right)$ akan berubah $=0,956 \mathrm{x}^{*}\left(\mathrm{X}_{2}\right)$, dengan asumsi variabel-variabel lain yang tidak diteliti tetap.

Uji hipotesis simultan dari penelitian ini disajikan dalam tabel 9, dengan hasil perhitungan statistik sebagai berikut :

Tabel 9.

Uji Simultan $X_{1}$ dan $X_{2}$ terhadap $Y$

\begin{tabular}{|c|c|c|c|c|c|c|}
\hline \multicolumn{7}{|c|}{ ANOVA $^{a}$} \\
\hline \multicolumn{2}{|c|}{ Model } & $\begin{array}{l}\text { Sum of } \\
\text { Squares }\end{array}$ & $d f$ & $\begin{array}{l}\text { Mean } \\
\text { Square }\end{array}$ & $\mathrm{F}$ & Sig. \\
\hline 1 & Regression & 1,451 & 2 &, 725 & 506,166 &, $000^{b}$ \\
\hline & Residual &, 013 & 9 &, 001 & & \\
\hline & Total & 1,464 & 11 & & & \\
\hline
\end{tabular}

a. Dependent Variable: VAR3 Laba Bruto

b. Predictors: (Constant), VAR2 Harga Pokok Produksi, VAR1 Imbalan Kerja

$\mathrm{F}_{\text {hitung }}=506,166, \mathrm{n}=12, \mathrm{k}=2, \alpha=0,05$, maka $F_{\text {tabel }}=3,885$. Karena $F_{\text {hitung }}>F_{\text {tabel }} . U j i$ signifikansi Sig. $=0,000<$ Alpha 0,05 maka model ini signifikan.Kesimpulanhipotesis model 3, Ho ditolak Ha diterima, yaitu terdapat dampak positif, signifikan antara Imbalan Kerja $\left(\mathrm{X}_{1}\right)$ dan Harga Pokok Produksi $\left(\mathrm{X}_{2}\right)$ terhadap Laba Bruto PT. Unilever Indonesia, Tbk.(Y).

\section{SIMPULAN DAN SARAN}

\section{SIMPULAN}

Penelitian ini dapat disimpulkan, berdasarkan analisis dan pembahasan pada bab sebelumnya, yaitu :

Terdapat dampak signifikan Imbalan Kerja terhadap Laba Bruto PT. Unilever Indonesia, Tbk., besarnya pengaruh tersebut 84,90 persen.

Terdapat dampak signifikan Harga Pokok Produksi terhadap Laba Bruto PT. Unilever, Tbk. dan dampak pengaruhnya sebesar 98,70 persen.

Terdapat pengaruh dan signifikan secara simultan antara Imbalan Kerja $\left(\mathrm{X}_{1}\right)$ dan Harga Pokok Produksi terhadap Total Biaya Produksi PT. Unilever Indonesia, Tbk. dan dampaknya sangat besar yaitu 99,10 persen.

\section{SARAN - SARAN}

Penelitian ini memberikan saran-saran, terkait simpulan yang dikemukakan terdahulu, adalah :

Perlunya perhitungan cermat dari Perseroan PT. Unilever Indonesia, Tbk. dalam pengadaan bahan baku dengan biaya efisien sehingga kontinyuitas pemasaran tetap terjaga dan mendorong supply kebutuhan rumah tangga masyarakat, yang selama pandemi Covid-19 mandeg karena PSBB.

Era pandemi covid-19 yang meluluh lantahkan perekonomian Indonesia, bahkan bisa terjadi Pemutusan Hubungan Kerja (PHK), maka Perseroan akan menghadapi pengeluaran imbalan kerja jangka panjang yang meningkat, hal ini harus tetap dinegosiasikan dengan Serikat Pekerja, sehingga laba perusahaan tidak semakin tergerus.

Perseroan adalah Multi National Corporation (MNC) dan Asosiasi-asosiasi industri nasional, diharapkan menjadi motor pendorong terwujudnya Undang-undang Omnibus Law Cipta Kerja, secara adil saling 
menguntungkan antara pengusaha dan para pekerja, tanpa menimbulkan ontran-ontran politik dengan maraknya demo jalanan, yang dapat mengganggu ketertiban masyarakat.

\section{DAFTAR PUSTAKA}

Adhi Lukman GAPMMI., Pandemi Covid-19 dan dampaknya terhadap industri olahan Indonesia" FGD GK Center, 13 April 2020

Buku Laporan Tahunan., Laporan Tahunan Kegiatan Usaha Dan Kinerja Keuangan 2008-2019. PT. Unilever Indonesia, Tbk.

Burhan Bungin,2013, Metodologi Penelitian Sosial dan Ekonomi Formar- format Kuantitatif dan Kualitatif, Kencana Prenada Media Group, Jakarta.

BPS (Badan Pusat Statistik)., 2020, Analisis Hasil Survei Dampak Covid-19 terhadap Pelaku Usaha. Penerbit BPS RI.

Financial Report., 2019., Total Biaya Produksi dan Biaya Tenaga Kerja Langsung . PT. Unilever Indonesia, Tbk.

John JOI Ihalauw., 2014, Permasalahan, Asumsi Filosofis Dasar dan Desain Penelitian" Fakultas Ekonomi dan Bisnis, Universitas Kristen Satyawacana, Indonesia.

Kasmir., 2011, Analisis Laporan Keuangan. Rajawali Pers.

Karunia Saputra., 2019, Komponen Laporan Laba Rugi: Laba Kotor vs Laba Bersih, Jurnal Entrepreneur., 2019.

Kristin Samah.,2018, Aswin Wirjadi GAME CHANGING Transformasi BCA 19902007. Gramedia Pustaka Utama

Mulyadi., 2012," Sistem Akuntansi". Salemba Empat, Jaga Karsa, Jakarta.

Rhenald Kasali., 2018, The Great SHIFTING. Gramedia Pustaka Utama.

RUU Cipta Kerja., 2019, Cipta Kerja Omnibus Law. DPR-RI

Sugiyono., 2017, Metode Penelitian Kombinasi, Alfabeta, Bandung.

Suliyanto., 2011, Ekonometrika Terapan Teori dan Aplikasi dengan SPSSCV.ANDI. Yogyakarta.
Sumadi Suryabrata., 2016, Metodologi Penelitian, PT. Raja Grafindo Persada. Depok.

Supriyono., 2013, Akuntansi Biaya I Edisi 2 : Pengumpulan Biaya dan Penentuan Harga Pokok. BPFE Yogyakarta.

Stephen Robbins, Mery Coulter.,2010, Manajemen. Gelora Aksara Pratama.

Taufik Hidayat., 2013, PSAK - 24 Akuntansi Imbalan Kerja. Fakultas Ekonomi Universitas Indonesia

V. Wiratna Sujarweni., 2019, Akuntansi Manajemen. Pustaka Baru Press, Yogyakarta.

Zaki Baridwan., 2012, Intermediate Accounting. Yogyakarta:BPFE.

Media Daring :

Accurate.id.Akuntansi., 2019, Pengertian Laba Kotor.

https://accurate.id/akuntansi/pengertian-labakotor-dan-perbedaannya-dengan-lababersih/

Repubilika.co.id,2019, Pertumbuhan Industri besar dan sedang.

https://www.republika.co.id/berita/ekonomi/k orporasi/pqvhfa370/pertumbuhanindustri-pengolahan-besar-dan-sedangmelambat

Okezone.com., 2008, Pabrik Unilver terbesar di Asia di bukahttps://lifestyle.okezone.com/read/ 2008/12/03/29/170371/pabrik-unilever-

terbesar-se-asia-resmi-dibuka

Tempo.co.bisnis., 2019, KSPI tolak RUU Omnibus Law Karena Jaminan Imbalan Kerja, Pensiun rendah. https://bisnis.tempo.co/read/1288723/to lak-omnibus-law-buruh-ancam-demodi-200-kabupaten-kota 